\title{
The child with jerking eyes and gait
}

\author{
Elizabeth Varkey Cherian, K Varadaraj Shenoy, Guruprasad Shetty, \\ Narasimha Reddy Ambati
}

Department of Pediatrics, Father Muller Medical College, Kankanady, Mangalore, Karnataka, India

\section{Correspondence to}

Dr Elizabeth Varkey Cherian, elizabeth.v.cherian@gmail.com
To cite: Cherian EV, Shenoy KV, Shetty G, et al. BMJ Case Reports Published online: [please include Day Month Year] doi:10.1136/ bcr-2012-008236

\section{MRI IMAGES OF BRAIN IN JOUBERT SYNDROME}

Joubert syndrome is a rare genetic disorder inherited as an autosomal recessive trait with an incidence of approximately 1 in 100000 children. Primarily it affects balance and coordination and is characterised by the partial or complete absence of cerebellar vermis and, dysplastic development of the midbrain.

MRI of the brain shows characteristic wisdom tooth appearance (figure 1) of the midbrain, secondary to the lack of decussation of the superior cerebellar peduncle which appears elongated along with a decreased diameter of the midbrain and a deep interpeduncular cistern. A bat wing appearance (figure 2) of the fourth ventricle is caused by the absence of the cerebellar vermis. The lateral ventricles and corpus callosum are normal.

This syndrome was first described by Marie Joubert, ${ }^{1}$ in 1969 in four siblings and one sporadic case that exhibited episodic hyperpnoea, abnormal eye movements, ataxia and mental retardation with cerebellar vermian agenesis and the midbrain hindbrain malformation.

The importance of this syndrome is related to the outcome and the potential complications that occur. A follow-up study of 19 children with Joubert syndrome showed neuromotor disability, developmental retardation or early death. ${ }^{2}$

These patients are sensitive to the respiratory depressant effects of anaesthetic agents which therefore must be avoided or need close perioperative respiratory monitoring.

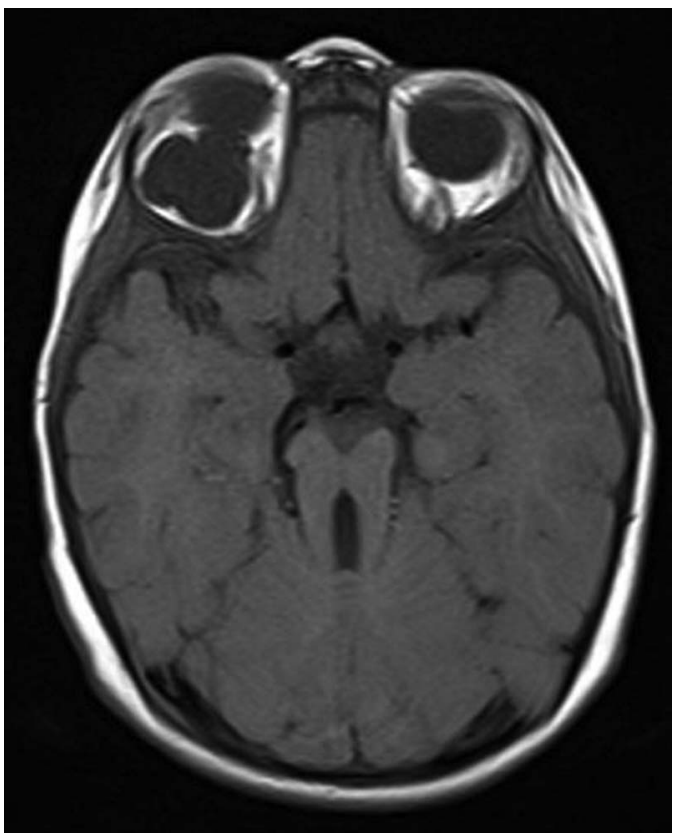

Figure 1 Molar tooth sign.

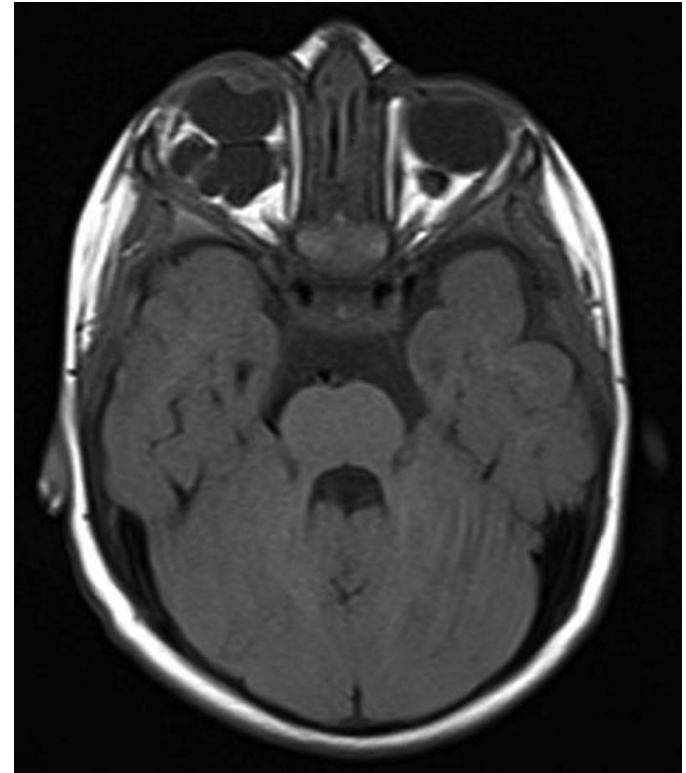

Figure 2 Bat wing appearance.

Once a diagnosis of Joubert syndrome is made in one neonate, antenatal diagnosis is possible by looking for these malformations in subsequent pregnancies.

\section{Learning points}

- Joubert syndrome is an inherited condition associated with developmental retardation, neuromotor disability and early death.

- Patients are extremely sensitive to the depressant effects of anaesthetic agents and require close perioperative respiratory monitoring.

- It is easy to identify the classical features on MRI brain. Antenatal diagnosis in subsequent pregnancies with ultrasound is possible.

Competing interests None.

Patient consent Obtained.

Provenance and peer review Not commissioned; externally pee reviewed.

\section{REFERENCES}

1 Joubert M, Eisenring JJ, Robb JP, et al. Familial agenesis of the vermis: a syndrome of episodic hyperpnea, abnormal eye movements, ataxia, and retardation. Neurology 1969;19:813-25.

2 Steinlin M, Schmid M, Landau K, et al. Follow-up in children with Joubert's syndrome. Neuropediatrics 1997;28:204-11. 
Copyright 2013 BMJ Publishing Group. All rights reserved. For permission to reuse any of this content visit http://group.bmj.com/group/rights-licensing/permissions.

BMJ Case Report Fellows may re-use this article for personal use and teaching without any further permission.

Become a Fellow of BMJ Case Reports today and you can:

- Submit as many cases as you like

- Enjoy fast sympathetic peer review and rapid publication of accepted articles

- Access all the published articles

- Re-use any of the published material for personal use and teaching without further permission

For information on Institutional Fellowships contact consortiasales@bmjgroup.com

Visit casereports.bmj.com for more articles like this and to become a Fellow 